\title{
Ziauddin Sardar (with Zafar Abbas Malik, illustrator), Introducing Islam: A Graphic Guide
}

(London: Icon Books, 2009), 176 pp. ISBN: 978-184831-084-1 (paperback). £6.99

\section{Saifullah Qamar Independent researcher, Kuala Lumpur}

Ziauddin Sardar (born in 1951 in Pakistan) is a well known London-based scholar, writer, and cultural-critic specialising in the present status and the future of Islam. He has written or edited some 45 books over a period of 30 years. Sardar also travels around the world analysing the current state of affairs concerning the modern Muslim world.

Introducing Islam belongs to a series of books (A Graphic Guide) which aims at educating the reader with the aid of beautifully drawn pictures and graphics to further enhance the learning experience. The main aim of this book is teaching and further enhancing the reader's knowledge of the basics of the Islamic religion and civilisation by recounting the history of the birth and spread of one of the greatest and most influential monotheistic religions in the world, and analysing the current negative issues affecting the development of the Muslim world and providing ideas on ways to curb them. Although this book is primarily aimed at non-Muslim readers, anyone including Muslim and non-Muslim (young or elderly) would be able to grasp quite a lot from this informative guide.

The many original illustrations and graphics on every page ensure that the reader comprehends and digests the text. Moreover, the author also indirectly voices his personal opinion on the subject he is explaining through a fictional character named 'Fez', who pops up every page or two and gives interesting and entertaining comments. In this way, not only does the author provide beneficial side notes, but also guides and communicates with the reader in a friendly way, making the book more interesting and enjoyable to read.

Starting with the biography of Prophet Muhammad, the author elaborates in chronological order the historical evolution of Islam and the Muslim world. The author covers almost every major aspect of Islam albeit not in significant detail. For example, he elaborates the significance of the Qur'ān and the Sunnah to the Muslims, how the Muslim society separated into two major divisions (Sunnis and Shi ites), and gives a brief history on the rule of the first four caliphs (also known as the Rightly Guided Caliphs) and how the Muslim world managed to expand via the expansion of the Muslim empires such as the Umayyads, Abbasids, and the Ottomans - to cover the lands that are presently part of the Muslim world.

Sardar also gives lengthy explanations on the literary, scientific, and technological advancements in the Muslim world. He elaborates on the works of many famous Muslim scholars, including Ibn Khaldūn, Ibn Sīnā, al-Jazarī and Ibn al-Haytham, 
to name just a few. Nevertheless, the most notable point is that Sardar offers the most criticism in this area. He mostly uses this opportunity to blame the West for 'stealing' the works of most of the Muslim scholars and making it 'their own' while getting the hard-earned credit for it. Perhaps in this attitude he reflects the sentiments of many Muslims, although one may object that the reality is more complex than this simplified portrait.

Among the many virtues of this handy, pocket-sized volume is the attention paid to challenging issues which many Muslims today living in Europe and America are constantly exposed to. Fundamentalism, the OIC, women's rights, modern reforms - many such topics are handled succinctly and informatively. But Sardar's voice is a progressive one, and he does not hesitate to take a position among the conflicting voices among Muslims today, as can clearly be seen in the section on women (pp. 160-2).

In most cases, this book uses fairly simple and comprehensible language to get the point across, even translating or explaining Arabic terms (which are frequently used in the text) such as ijtiha $\bar{d}$ and $a d a b$ explicitly. The final three pages comprise an 'Index and Little Dictionary', serving the double purpose of a guide to contents and an explanation of key Islamic terms and concepts. Alongside this Sardar provides a two-page guide to 'Further Reading' which is quite judicious in selecting English language titles to promote further reflection and research. This book is no 'Harry Potter' for young readers since it is intellectually challenging and is really aimed at adults. But it may be described as a model among books for learners and seekers of knowledge due to its style of approach and its contents.

Nevertheless, even a rose has thorns. Although this book explains almost everything the average person might wish to know about Islam, there are instances where the language used to explain a certain point is slightly unclear or rather laborious to comprehend. For example, the author sometimes uses terms that are not particularly friendly to younger readers - words such as 'coercion', 'usurp', 'ossified' 'proviso', or 'exonerated', to name just a few. Despite this, if one is looking for an easily digestible book to further understand the beautiful and significant monotheistic religion of Islam or to clear any remaining accumulated doubt regarding it, then Introducing Islam: A Graphic Guide would be a good choice. 